\title{
Kesepian Sebagai Mediator antara Dukungan Sosial dengan Kecenderungan Adiksi Video Game pada Anak
}

\author{
Handini Hardianti ${ }^{1}$, Supra Wimbarti² \\ Fakultas Psikologi, Universitas Gadjah Mada \\ J1. Sosio Humaniora Bulaksumur, Karang Malang, Caturtunggal, Kec. Depok, Kabupaten Sleman \\ Daerah Istimewa Yogyakarta 552812 \\ Handini.hardianti@gmail.com¹, supra@ugm.ac.id²
}

\begin{abstract}
Abstrak
Bermain adalah kebutuhan bagi anak, meskipun saat ini memainkan video game lebih banyak diminati dibanding permainan tradisional. Kemudahan untuk mengakses permainan video game yang berlebihan dapat mengakibatkan munculnya masalah. Penelitian ini bertujuan untuk mengetahui hubungan antara rendahnya dukungan sosial offline dan kecenderungan adiksi video game dimediasi oleh kesepian pada anak usia akhir. Penelitian ini dilakukan dengan metode survei yang melibatkan 308 anak dengan rentang usia 9-12 tahun. Analisis menggunakan regresi berganda dan SEM berdasarkan komponen. Hasil penelitian ini menunjukkan bahwa semakin rendah dukungan sosial offline berpengaruh terhadap meningkatnya kesepian secara langsung. Anak dengan dukungan sosial offline yang rendah berdampak pada meningkatnya kecenderungan adiksi video game secara langsung, namun begitu anak yang merasa kesepian tidak berpengaruh pada kecenderungan adiksi video game yang tinggi. Hipotesis pada penelitian ini ditolak, yaitu kesepian tidak berperan sebagai mediator dalam hubungan antara rendahnya dukungan sosial offline dan kecenderungan adiksi video game dengan koefisien tak langsung sebesar -0.066 (sig > 0.05), namun kesepian dan rendahnya dukungan sosial offline berperan sebagai variabel prediktor terhadap kecenderungan adiksi video game dengan sumbangan efektif sebesar $10.3 \%$. Artinya bahwa semakin anak merasa kesepian dan mendapat dukungan sosial offline yang rendah, semakin tinggi kecenderungannya menjadi adiksi video game.
\end{abstract}

Kata kunci: rendahnya dukungan sosial offline, kecenderungan adiksi video game, kesepian

\begin{abstract}
Playing is a necessity for children, although currently playing video game is more in demand than traditional games. The ease of accessing video game play results in problems associated with excessive video game use. The aim of this study is to examine the role of loneliness in mediating relationship between low offline social support and tendency of video game addiction. This research was conducted by a survey method involving 308 elementary school students aged 9-12 years living in Malang City. This study uses multiple regression analysis and SEM based on components. The results of this study indicate that lower offline social support has an effect on increasing loneliness directly. Children with low offline social support have an impact on the increasing tendency of video game addiction directly, however, children who feel lonely have no effect on the high tendency of video game addiction. The hypoothesis in this study is rejected, loneliness does not act as a mediator in the relationship between the low level of offline social support and the tendency of video game addiction with an indirect coefficient of -0.066 ( $\mathrm{sig}>0.05)$, but loneliness and low offline social support plays a role as a predictive variable towards the tendency of video game addiction with an effective contribution of $10.3 \%$. This means that the more lonely children feel and receive low offline social support, the higher the tendency to become video game addiction.
\end{abstract}

Keywords: low offline social support, tendency of video game addiction, loneliness

\section{PENDAHULUAN}

Perkembangan video game saat ini sangat pesat, sehingga perlu disikapi secara benar sebagai upaya agar anak tidak mengalami adiksi pada video game. Berdasarkan survey yang dilakukan di Malaysia, Filipina dan Indonesia, menunjukkan sebanyak 98\% orang tua mengijinkan anaknya untuk menggunakan gadget, dan orang tua dari anak-anak berusia 3-8 tahun mengatakan bahwa penggunaan gadget tersebut adalah untuk main game (72\%), melihat 
tayangan video (60\%), aplikasi untuk pendidikan (57\%), diikuti dengan aplikasi lucu dan menyenangkan (31\%), serta buku (14\%) (The Asian Parent Insight, 2014). Daya tarik video game bagi anak-anak sangat besar, ditambah dengan kemudahan akses yang menyebabkan kecenderungan adiksi menjadi semakin tinggi. Beberapa penelitian sebelumnya lebih banyak dilakukan pada subjek remaja dan dewasa, padahal anak-anak juga merupakan pemain video game yang aktif. Penelitian yang dilakukan pada 184 pemain game online dengan subjek mulai dari usia sekolah hingga dewasa muda menunjukkan bahwa semakin muda usia seseorang maka semakin besar kecenderungannya dalam bermain game online (Kusumadewi, 2009). Lemmens, Valkenberg, dan Peter (2009) juga menyatakan bahwa anak dianggap lebih sering dan sangat rentan terhadap penggunaan permainan game online daripada orang dewasa.

Berbeda dengan bermain permainan tradisional yang memiliki lebih banyak kesempatan untuk bersosialisasi dan bertemu dengan satu sama lain, anak-anak pada saat ini lebih suka bermain video game sendiri (Tavormina dan Tavormina, 2017). Anak-anak yang cenderung terus-menerus bermain game online dan menghindari hubungan sosial memiliki kecenderungan adiksi dengan video game (Bray, 2008). Kecenderungan adiksi video game pada penelitian ini dioperasionalisasikan sebagai penggunaan video game secara berlebihan dan kompulsif dimana penggunanya tidak dapat mengontrol perilaku tersebut dan karenanya dapat menimbulkan permasalahan sosial dan/atau emosional. Kecenderungan adiksi video game dapat diukur berdasarkan kriteria DSM 5, yaitu: praokupasi, toleransi, penarikan diri atau withdrawal, persistensi, melarikan diri (escape), muncul permasalahan, adanya penipuan (deception), displacement, dan muncul konflik. Indikasi adiksi yang tinggi diperoleh dari semakin banyak atau parahnya gangguan yang dialami. Pada penelitian ini, adiksi bukan dinilai sebagai sebuah diagnosa bahwa seorang anak tergolong kecanduan atau tidak, tetapi hanya sebagai kecenderungan saja.

Berkaitan dengan hal ini, beberapa studi menyebutkan bahwa calon pecandu internet berasal dari orang yang kesepian dan pemalu, sedangkan orang yang lebih tangguh dapat melindungi dirinya dari kecanduan internet (Wimbarti, 2018). Lemmens (2015) menyatakan bahwa kesepian mengindikasikan hubungan yang resiprokal dengan adiksi. Artinya kesepian merupakan penyebab dan konsekuensi dari bermain game online yang patologis. Anak yang merasa kesepian akan mencari pengalihan dengan bermain video game secara terus menerus. Perilaku bermain game yang terus menerus tersebut mengakibatkan anak kurang bersosialisasi dengan lingkungan di dunia nyatanya sehingga anak menjadi semakin kesepian. Kesepian pada penelitian ini didefinisikan sebagai perasaan tidak menyenangkan yang melibatkan kesadaran kognitif akan berkurangnya hubungan sosial dan personal seseorang dan menunjukkan reaksi afektif seperti kesedihan, kekosongan, dan kerinduan.

Weiss (dalam Santrock, 2013) memandang kesepian sebagai konstrak multidimensional dan membagi kesepian menjadi kesepian sosial dan kesepian emosional. Kesepian secara sosial ditujukan bagi seseorang yang kurang memiliki teman dan berhubungan dengan ketiadaan atau sedikitnya teman dekat. Kesepian secara emosional mengindikasikan sedikitnya intimasi dengan teman dekat dan tidak ada hubungannya dengan jumlah teman dekat yang dimiliki. Kesepian pada anak sekolah dasar berhubungan dengan rendahnya pengakuan dan perhatian dari teman sebayanya (Rotenberg, 2004). Kesepian juga berpengaruh secara langsung terhadap preferensi pada interaksi online karena individu yang kesepian tersebut merasa bahwa mereka lebih dapat berekspresi dan melakukan interaksi dengan orang lain secara lebih baik pada saat online daripada offline (Pontes, Griffiths, Patrao, 2014). 
Berbicara mengenai interaksi sosial, Knoetze (2012) berpendapat bahwa anak-anak usia akhir pada dasarnya ingin melakukan sesuatu sendiri, namun mereka masih membutuhkan orang dewasa yang siap membantu ketika dibutuhkan. Mereka lebih menghargai hubungan dengan orang tua, kakak-adik yang sekandung, dan teman sebaya. Partisipasi sosial meluas selama anak-anak usia akhir (Knoetze, 2012). Dukungan sosial merupakan bentuk anggapan positif dari orang lain atau penerimaan seseorang sebagai individu dikaitkan dengan harga diri atau tingkat dimana seseorang menyukai diri sendiri sebagai pribadi, menyukai cara seseorang menjalani hidupnya, merasa puas dengan diri sendiri dan secara umum merasa senang dengan dirinya. Dukungan sosial offline merupakan dukungan yang diperoleh dari lingkungan nyata (offline), Menurut Harter (2012), dukungan tersebut berasal dari orang tua, sahabat, teman sekelas, keluarga, ataupun guru yang pada penelitian ini ditekankan bertemu secara langsung (bukan online). Penerimaan dukungan sosial diukur dengan menggunakan modifikasi skala dukungan sosial pada anak yang disusun oleh Harter (2012). Individu yang memiliki dukungan sosial offline yang tinggi, diprediksikan memiliki kecenderungan adiksi video game yang rendah.

Dukungan sosial memiliki dampak yang positif pada individu, dapat menjadi faktor proteksi dari depresi dan perasaan kesepian (Tabak \& Zawadzka, 2017). Kurangnya dukungan sosial berhubungan dengan penyimpangan perilaku, perilaku agresif, depresi, dan masalah sekolah (Hagen, Myers, dan Mackintosh, 2005). Anak-anak mempelajari cara untuk menyelesaikan masalah sebagai bagian dari dukungan sosial yang disediakan oleh orang-orang penting dalam kehidupannya. Dukungan sosial dari orangtua sangat penting bagi anak usia sekolah, karena pada masa ini orang tua tidak hanya berperan sebagai panutan dan sumber informasi, tetapi mereka juga membela, mendukung, dan sebagai pengukur akses bagi anak agar aktif dalam lingkungannya (Poole, Eiriksdottir, Miller, Xu, Catrambone, Mynatt, 2013).

Seseorang yang merasakan kesepian dan kurang mendapatkan dukungan sosial yang nyata dari lingkungannya mempunyai kesempatan yang lebih besar untuk mencoba menggali identitasnya di dunia maya yang mungkin lebih menyenangkan jika dibandingkan dengan seseorang yang kurang atau tidak merasa kesepian. Hal ini didukung oleh Leung (2011) yang menyatakan bahwa kesepian dan dukungan sosial dari lingkungan yang nyata (offline) memiliki hubungan yang signifikan dengan interaksi sosial di dunia maya (online). Teknologi yang berkembang pesat secara otomatis membuat anak semakin terpapar dengan berbagai sarana teknologi, salah satunya video game. Berkaitan dengan hal tersebut, penelitian ini ingin mengungkap bahwa anak dapat mengalami kecenderungan adiksi video game yang diakibatkan karena kurangnya dukungan sosial offline yang dirasakan, sehingga menyebabkan anak tersebut merasa kesepian dan mulai bermain video game secara terus menerus, atau dengan kata lain, rendahnya dukungan sosial offline dapat menyebabkan anak merasa kesepian sehingga kecenderungan adiksi video game menjadi tinggi. Dinamika tersebut yang melatarbelakangi diajukannya hipotesis pada peneitian ini, yaitu adanya peran kesepian sebagai mediator hubungan antara rendahnya dukungan sosial offline dan kecenderungan adiksi video game.

\section{METODE}

Penelitian ini dilakukan di beberapa sekolah dasar yang berada di Kota Malang. Subjek penelitian berusia sekitar 9 hingga 12 tahun. Pemilihan subjek dengan menggunakan metode purposive sampling. Pada penelitian ini, data dikumpulkan dengan menggunakaan skala yang terdiri dari skala kecenderungan adiksi video game, skala kesepian dan penerimaan dukungan 
sosial offline yang diisi langsung oleh anak. Pemberian skala dilakukan di kelas pada saat jam sekolah dengan pendampingan dari guru sekolah dan tim peneliti. Sejumlah 330 anak mengikuti penelitian ini, namun 22 anak di antaranya tidak memenuhi kriteria. Adapun 22 anak tersebut terdiri dari 12 orang bukan pemain game, 5 orang tidak mengisi skala secara lengkap, 1 orang tidak memenuhi kriteria usia, dan 4 orang datanya terhitung sebagai outliers. Total subjek dalam penelitian ini adalah 308 anak yang terdiri dari 152 laki-laki dan 156 perempuan.

Skala kecenderungan adiksi video game pada penelitian ini merupakan bentuk adaptasi dari skala Lemmens dkk (2015) yang terdiri dari 9 indikator dan 27 aitem pada skala awal. Setelah melalui uji coba, skala kecenderungan adiksi video game terdiri dari 24 aitem dengan Cronbach's Alpha 0,893. Contoh aitem pada skala ini adalah: "Saya terus menerus berpikir tentang game saat sedang di sekolah". Skala kesepian merupakan skala yang dimodifikasi berdasarkan Asher dkk (1984) yang terdiri dari 16 aitem awal. Pada skala ini, terdapat 2 aitem yang gugur sehingga skala kesepian berisi 14 aitem dengan Cronbach's Alpha 0,857. Contoh aitem pada skala kesepian adalah: "Saya mudah berkenalan dengan teman baru di sekolah", "Saya sulit membuat teman-teman di sekolah menyukai saya". Skala dukungan sosial disusun berdasarkan teori Harter (2012) tentang dukungan sosial pada anak yang berasal dari orangtua, teman sekelas, guru, dan teman dekat. Setelah uji coba, jumlah aitem 23 dengan nilai Cronbach's Alpha 0,861. Contoh aitem yang terdapat pada skala dukungan sosial seperti: "Saya memiliki teman sekelas yang bisa saya sayangi", "Saya mempunyai orang tua yang perhatian dengan perasaan saya".

\section{HASIL}

Tabel 1.

Deskripsi data penelitian

\begin{tabular}{llll}
\hline Kriteria & Dekripsi & Frekuensi & persentasase \\
\hline Jenis Kelamin & Laki-laki & 152 & $49,4 \%$ \\
\hline Usia & Perempuan & 156 & $50,9 \%$ \\
\hline & 9 & 19 & $6,2 \%$ \\
\hline & 10 & 110 & $35,7 \%$ \\
\hline Pekerjaan orang tua & 11 & 140 & $45,5 \%$ \\
\hline & Keduanya berkerja & 39 & 150 \\
\hline Kepemilikian HP & Salah satu bekerja & 158 & $48 \%$ \\
\hline & HP Pribadi & 264 & $52 \%$ \\
\hline Durasi & Bukan HP Pribadi & 44 & $14,7 \%$ \\
\hline & $1-2$ Jam & 154 & $50 \%$ \\
\hline & $2-3$ jam & 92 & $29,9 \%$ \\
\hline & $3-4$ jam & 37 & $12 \%$ \\
\hline Jenis game & $>4$ & 25 & $8,1 \%$ \\
\hline & Offline & 146 & $47,4 \%$ \\
\hline
\end{tabular}

Berdasarkan tabel 1 di atas ada 156 subjek yang berjenis kelamin perempuan dengan persentase $50.6 \%$, sedangkan subjek laki-laki sejumlah 152 anak dengan persentase $49.4 \%$. Tabel 17 menunjukkan frekuensi mengenai subjek berdasarkan usianya. Kemudian subjek yang berusia 11 tahun sejumlah 140 anak dengan persentase $45.5 \%$, terbanyak kedua adalah subjek yang berusia 10 tahun sejumlah 110 anak dengan persentase $35.7 \%$. Subjek yang berusia 12 tahun sejumlah 39 anak dengan persentase 12.7\% sedangkan subjek yang berusia 9 tahun hanya 19 anak dengan persentase 6.2\%. Diketahui bahwa anak yang bermain dalam jangka waktu 3-4 jam per harinya memiliki rata-rata dukungan sosial offline yang rendah, disusul 
dengan anak yang bermain dalam jangka waktu 1-2 jam, kemudian anak yang bermain lebih dari 4 jam. Mayoritas subjek bermain dengan durasi 1-2 jam per harinya, kelompok inilah yang nilai rata-rata dukungan sosialnya lebih tinggi dibanding kelompok yang lainnya. Sebanyak 162 subjek dalam penelitian ini atau sekitar 52.6\% memainkan game online, sedangkan 146 subjek atau sekitar $47.4 \%$ lainnya memainkan game offline.

Tabel 2.

Perbandingan Nilai Rata-rata Variabel Berdasarkan Rating Game

\begin{tabular}{lcccc}
\hline \multicolumn{1}{c}{ Variabel } & $\begin{array}{c}\text { Durasi } \\
\text { bermain game }\end{array}$ & Nilai Rata-rata & Nilai F & Sig. \\
\hline \multirow{3}{*}{ Rendahnya } & $3+$ & 41.10 & 3.341 & 0.011 \\
dukungan sosial & $7+$ & 44.37 & & \\
offline & $12+$ & 47.00 & & \\
& $16+$ & 48.71 & & \\
& $18+$ & 53.25 & & \\
Kesepian & $3+$ & 25.57 & 0.617 & 0.651 \\
& $7+$ & 26.44 & & \\
& $12+$ & 29.00 & & \\
& $16+$ & 28.00 & & \\
Kecenderungan & $18+$ & 24.00 & & \\
Adiksi Video Game & $3+$ & 35.35 & 8.189 & \\
& $7+$ & 41.79 & & \\
& $12+$ & 40.50 & & \\
& $16+$ & 47.71 & & \\
\hline
\end{tabular}

Berdasarkan rating game, terdapat perbedaan yang signifikan pada rata-rata kecenderungan adiksi video game, yang lebih tinggi adalah game dengan rating $16+($ mean $=47.71)$ dan rating 18+ (mean=43.25). Anak yang memainkan game dengan rating $18+$ memiliki rata-rata dukungan sosial yang lebih rendah daripada rating yang lain. Anak dengan dukungan sosial offline yang lebih rendah cenderung memainkan game dengan rating yang lebih tinggi atau tidak sesuai dengan usianya.

Tabel 3.

Hasil Uji F pada variabel kesepian dan rendahnya dukungan sosial offline

\begin{tabular}{ccccccc}
\hline \multirow{2}{*}{ Model } & $\begin{array}{c}\text { Sum of } \\
\text { Squares }\end{array}$ & df & Mean Square & F & Sig. \\
\hline 1 & Regression & 3618.720 & 2 & 1809.360 & 17.555 & $.000 \mathrm{~b}$ \\
& Residual & 31436.017 & 305 & 103.069 & & \\
& Total & 35054.737 & 307 & & & \\
\hline
\end{tabular}

Pengujian regresi berganda menghasilkan nilai signifikansi kurang dari 0.05. Hal tersebut memiliki arti bahwa dukungan sosial offline yang rendah dan kesepian secara bersama-sama memiliki pengaruh yang nyata pada kecenderungan adiksi video game.

Berdasarkan nilai koefisien determinasi, nilai $\mathrm{R}^{2}$ sebesar 0.103 , artinya bahwa variabel kesepian dan dukungan sosial offline yang rendah berpengaruh sebesar $10.3 \%$ terhadap 
kecenderungan adiksi video game, sedangkan $89.7 \%$ lainnya dipengaruhi variabel-variabel lain yang tidak diteliti dalam penelitian ini.

Pada pemodelan persamaan struktural pendekatan PLS, beberapa pengujian yang dilakukan yaitu: (1) Pengujian Asumsi dalam PLS, (2) pengujian goodness of fit model struktural, (3) pendugaan model pengukuran (outer model), (4) pendugaan model struktural (inner model), dan (5) pengujian efek mediasi. Model struktural yang akan diuji tercantum pada gambar 1.

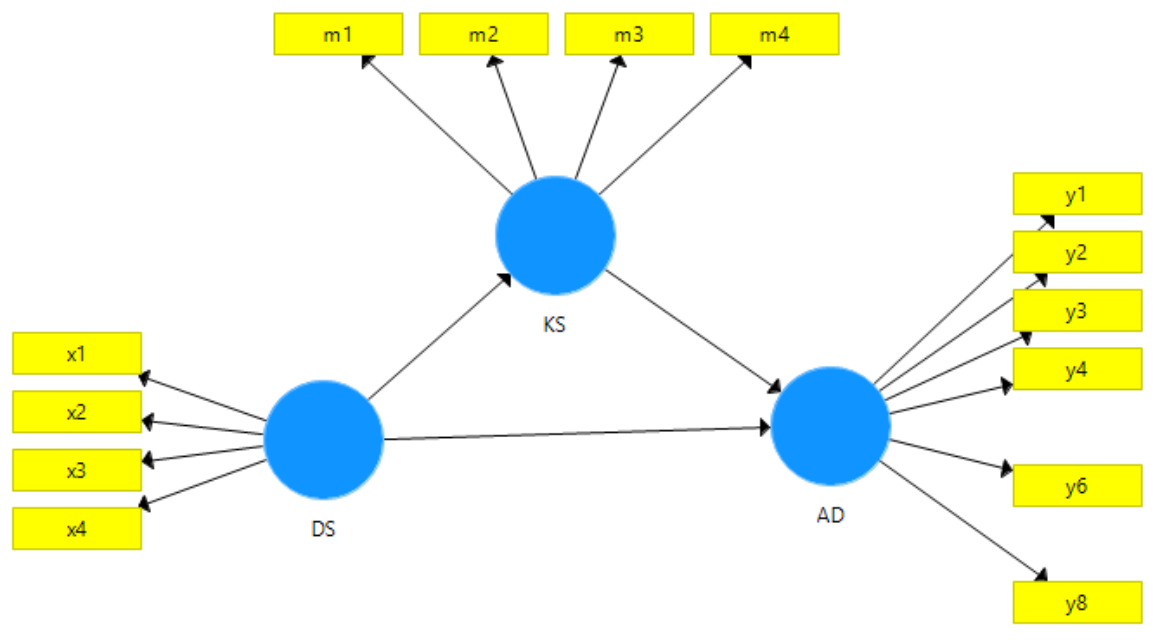

Gambar 1 Model Struktural Konseptual

Berdasarkan gambar model struktural konseptual di atas, dapat dijelaskan bahwa model konseptual tersebut dapat dibagi ke dalam dua buah model berdasarkan variabel dependennya, yakni model 1 yaitu model yang menggambarkan pengaruh langsung antara rendahnya dukungan sosial offline (X) terhadap Kesepian (M). Model 2, yakni model yang menggambarkan pengaruh langsung rendahnya dukungan sosial offline (X), kesepian (M) terhadap kecenderungan adiksi video game (Y).

Tabel 4.

$\mathrm{R}^{2}$ dan $\mathrm{Q}^{2}$ Model Struktural

\begin{tabular}{ccc}
\hline Model Struktural & $\mathrm{R}^{2}$ & $\mathrm{Q}^{2}$ \\
\hline Model 1 & 0.128 & \multirow{2}{*}{0.457} \\
Model 2 & 0.354 & \\
\hline
\end{tabular}

$\mathrm{Q}^{2}=1-\left(1-\mathrm{R}_{1}^{2}\right)\left(1-\mathrm{R}_{2}^{2}\right) \ldots\left(1-\mathrm{R}_{\mathrm{p}}^{2}\right)$

$\mathrm{Q}^{2} \quad=1-(1-0.128)(1-0.354)$

$=1-(0.782 \times 0.646)$

$=1-0,505$

$=0,495$

Berdasarkan pengujian model goodness of fit, nilai predictive-relevance $\left(Q^{2}\right)$ yang ditunjukkan melalui hasil perhitungan sebesar 0.495 atau 49.5\%. Nilai tersebut merupakan nilai predictive relevance. Nilai ini mengindikasikan bahwa model tersebut dapat menjelaskan keragaman data sebesar 49.5\%. Hal ini berarti bahwa model tersebut dapat menjelaskan informasi dari data yang ada sebanyak $49.5 \%$. Sedangkan $50.5 \%$ sisanya dijelaskan oleh variabel-variabel lain (yang belum terdapat dalam model) dan derajat kesalahan (error). 
Tabel 5.

Pengujian Convergent Validity Outer Model

\begin{tabular}{lcccc}
\hline \multicolumn{1}{c}{ Outer Model } & $\begin{array}{c}\text { Outer } \\
\text { Loading }\end{array}$ & T-Statistic & P-value & AVE \\
\hline X1 <- RDS- Orang tua & 0.760 & 23.665 & 0.000 & \\
X2 <- RDS- Teman Sekelas & 0.797 & 31.973 & 0.000 & \multirow{2}{*}{0.600} \\
X3 <- RDS-Guru & 0.695 & 16.714 & 0.000 & \\
X4 <- RDS-Teman Dekat & 0.862 & 57.235 & 0.000 & \\
m1 <- KS-Perasaan Kesepian anak & 0.716 & 13.811 & 0.000 & \\
m2 <- KS-hubungan penting terpenuhi & 0.770 & 21.108 & 0.000 & \\
m3 <- KS-kompetensi sosial & 0.777 & 26.990 & 0.000 & 0.609 \\
m4 <- KS-hubungan dengan teman dekat & 0.831 & 32.210 & 0.000 & \\
y1 <- AD-preokupasi & 0.837 & 36.025 & 0.000 & \\
y2 <- AD-toleransi & 0.837 & 33.954 & 0.000 & \\
y3 <- AD-penarikan diri & 0.768 & 20.760 & 0.000 & \multirow{2}{*}{0.584} \\
y4 <- AD-persistence & 0.676 & 13.644 & 0.000 & \\
y6 <- AD-problem & 0.718 & 19.592 & 0.000 & \\
y8 <- AD-pengalihan & 0.734 & 19.783 & 0.000 & \\
\hline
\end{tabular}

Berdasarkan pada hasil pengujian model struktural dengan metode PLS di atas, langkah berikutnya adalah menguji outer model struktural pada indikator-indikator pembentuk variabel laten. Langkah pertama pengujian outer model adalah dengan convergent validity pada indikator-indikator pembentuk variabel laten. Pengujian ini dilakukan untuk menentukan tingkat validitas indikator terhadap variabel latennya. Indikator individu dianggap valid jika memiliki nilai outer loading di atas 0,7 atau nilai T-Statistic di atas 1,96 dan p-value kurang dari 0.05 (Jogiyanto dan Abdillah, 2009). Hasil uji convergent validity outer model refleksif, ditemukan bahwa pada variabel kecenderungan adiksi video game (Y), indikator preoccupation (Y1) dan tolerance (Y2) memiliki nilai outer loading yang paling besar. Hal ini mengindikasikan bahwa kontribusi paling besar terhadap variabel kecenderungan adiksi video game (Y) diukur oleh preoccupation (Y1) dan tolerance (Y2). Pada variabel dukungan sosial offline (X), indikator teman dekat (X4) memiliki nilai outer loading yang paling besar. Hal ini mengindikasikan bahwa kontribusi paling besar terhadap variabel dukungan sosial offline (X) diukur oleh indikator teman dekat (X4). Pada variabel kesepian (M), indikator penilaian anak mengenai hubungan dengan teman sebayanya saat ini (M4) memiliki nilai outer loading yang paling besar. Hal ini mengindikasikan bahwa kontribusi paling besar terhadap variabel kesepian (M) diukur oleh indikator penilaian anak mengenai hubungan dengan teman sebayanya saat ini (M4).

Indikator penyusun variabel laten (outer model) terpenuhi, langkah selanjutnya adalah melakukan pengujian pada inner model struktural. Pengujian inner model (structural model) pada intinya menguji hipotesis dalam penelitian. Pengujian hipotesis dilakukan dengan uji t (Tstatistic) pada masing-masing jalur pengaruh langsung secara parsial. 


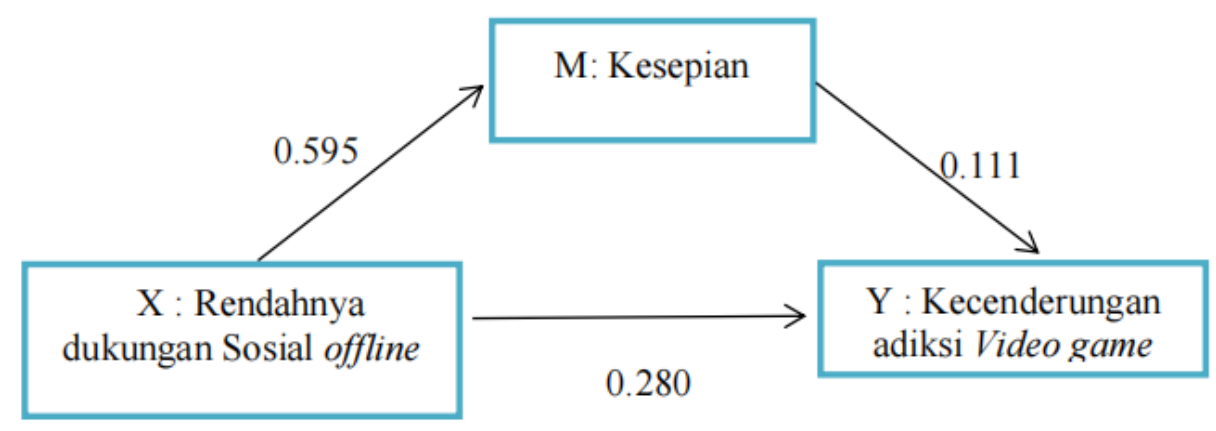

Gambar 2 Diagram Jalur Hasil Pengujian Hipotesis Inner Model

Pada Model 1, jalur pengaruh antara dukungan sosial offline (X) terhadap kesepian (M), variabel rendahnya dukungan sosial offline $(\mathrm{X})$ memberikan pengaruh positif yang signifikan pada kesepian (M). Kualitas yang semakin rendah dari dukungan sosial offline, maka akan berdampak pada meningkatnya kesepian secara langsung atau dengan kata lain, dukungan sosial yang tinggi dapat menurunkan kesepian secara langsung.

Pada Model 2, jalur pengaruh antara rendahnya dukungan sosial offline (X) dan kesepian (M) terhadap kecenderungan adiksi video game (Y), variabel rendahnya dukungan sosial offline $(\mathrm{X})$ memberikan pengaruh positif dan signifikan terhadap kecenderungan adiksi video game (Y). Semakin tinggi dukungan sosial offline, berdampak pada meningkatnya kecenderungan adiksi video game secara langsung. Jalur pengaruh antara kesepian (M) terhadap kecenderungan adiksi video game (Y), variabel kesepian (M) memberikan pengaruh yang positif terhadap kecenderungan adiksi video game $(\mathrm{Y})$, namun pengaruhnya tidak signifikan.

Tabel 6.

Hasil Pengujian Pengaruh Langsung Inner Model

\begin{tabular}{|c|c|c|c|}
\hline Jalur Pengaruh Langsung & $\begin{array}{l}\text { Koefisien Pengaruh } \\
\text { Langsung }\end{array}$ & $\begin{array}{c}\mathrm{T}- \\
\text { Statistic }\end{array}$ & p-value \\
\hline $\begin{array}{l}\text { Rendahnya Dukungan Sosial_offline (X) -> } \\
\text { kecenderungan Adiksi Video Game (Y) }\end{array}$ & 0.280 & 4.023 & $0.000^{* *}$ \\
\hline $\begin{array}{l}\text { Rendahnya Dukungan Sosial_offline (X) -> } \\
\text { Kesepian (M) }\end{array}$ & 0.595 & 16.531 & $0.000 * *$ \\
\hline $\begin{array}{l}\text { Kesepian (M) -> kecenderungan Adiksi_Video } \\
\text { Game (Y) }\end{array}$ & 0.111 & 1.533 & 0.126 \\
\hline
\end{tabular}

Variabel rendahnya dukungan sosial offline memberikan pengaruh positif terhadap kecenderungan adiksi video game dengan koefisien jalur sebesar 0.280 dimana koefisien jalur tersebut lebih besar daripada kesepian (M). Hal ini menunjukkan bahwa dukungan sosial offline (x) memberikan pengaruh langsung yang lebih besar terhadap kecenderungan adiksi video game (Y). Pada pengujian pengaruh langsung variabel rendahnya dukungan sosial offline (X) terhadap kesepian (M), didapatkan koefisien jalur sebesar 0.595 dengan p-value sebesar 0.000. P-value kurang dari 0,05 menunjukkan bahwa variabel rendahnya dukungan sosial offline (X) memberikan pengaruh yang positif dan signifikan terhadap kesepian (M). Hal ini berarti bahwa semakin rendah dukungan sosial offline, berdampak pada meningkatnya kesepian secara langsung. Hasil penelitian ini juga sama dengan hasil penelitian sebelumnya 
yaitu dukungan sosial memiliki dampak yang positif pada individu yaitu dapat menjadi faktor proteksi dari perasaan kesepian (Tabak \& Zawadzka, 2017).Anak-anak akan lebih baik ketika mereka berada pada jaringan sosial yang efektif yang dapat memberikan dukungan dan arahan (Hagen, Myers, dan Mackintosh, 2005).

Pengaruh total (total effect) variabel independen dan mediasi terhadap variabel Kecenderungan adiksi Video game (Y) juga diuji selain menguji pengaruh langsung variabel bebas terhadap variabel terikat.

Tabel 7.

Hasil Pengujian Hipotesis Pengaruh Total Inner Model

\begin{tabular}{lccc}
\hline \multicolumn{1}{c}{ Total Effect } & $\begin{array}{c}\text { Koefisien Total } \\
\text { Effect }\end{array}$ & $\begin{array}{c}\text { T- } \\
\text { Statistic }\end{array}$ & $\begin{array}{c}\mathrm{p}- \\
\text { value }\end{array}$ \\
\hline $\begin{array}{l}\text { Rendahnya Dukungan Sosial_offline (X) -> } \\
\text { kecenderungan Adiksi_Video Game (Y) }\end{array}$ & 0.346 & 6.949 & 0.000 \\
Kesepian (M) -> kecenderungan Adiksi_Video Game (Y) & 0.111 & 1.533 & 0.126 \\
\hline
\end{tabular}

Hasil dari penjumlahan pengaruh langsung dan pengaruh tak langsung variabel independen terhadap variabel dependen disebut sebagai pengaruh total. Pengaruh total variabel ditunjukkan melalui total effect variabel independen. variabel dukungan sosial offline (X) memiliki total effect sebesar $0.346(\mathrm{p}<0.01)$ dan variabel kesepian $(\mathrm{M})$ memiliki total effect sebesar 0.111 $(\mathrm{p}>0.05)$. Total effect variabel dukungan sosial offline $(\mathrm{X})$ lebih besar daripada variabel kesepian (M).

Tabel 7.

Hasil Pengujian Efek Mediasi Variabel Kesepian

\begin{tabular}{ccccc}
\hline Variabel Eksogen & $\begin{array}{c}\text { Variabel } \\
\text { Mediasi }\end{array}$ & Variabel Endogen & $\begin{array}{c}\text { Pengaruh Tak } \\
\text { Langsung }\end{array}$ & $\begin{array}{c}\text { P- } \\
\text { value }\end{array}$ \\
\hline $\begin{array}{c}\text { Rendahnya Dukungan } \\
\text { Sosial offline }(\mathrm{X})\end{array}$ & $\begin{array}{c}\text { Kesepian } \\
(\mathrm{M})\end{array}$ & $\begin{array}{c}\text { Kecenderungan adiksi } \\
\text { Video game }(\mathrm{Y})\end{array}$ & 0.066 & 0.132 \\
\hline
\end{tabular}

Pengaruh tak langsung diuji dengan menggunakan Sobel Test. Pengaruh tak langsung Variabel rendahnya Dukungan Sosial offline (X) terhadap Kecenderungan adiksi Video game (Y) melalui Variabel Kesepian (M) sebagai mediasi adalah sebesar 0.066 dan p-value sebesar 0.132. P-value lebih dari 0.05 mengindikasikan bahwa pengaruh tak langsung tidak signifikan, sehingga dari pengujian dengan Sobel Test tidak terbukti bahwa variabel kesepian (M) merupakan variabel mediasi yang menghubungkan variabel dukungan sosial offline (X) terhadap kecenderungan adiksi video game (Y).

\section{DISKUSI}

Penelitian ini menemukan bahwa semakin rendah dukungan sosial offline, berdampak pada meningkatnya kesepian secara langsung. Hasil penelitian ini sesuai dengan penelitian sebelumnya yang menyatakan bahwa dukungan sosial memiliki dampak yang positif pada individu yaitu dapat menjadi faktor proteksi dari perasaan kesepian (Tabak \& Zawadzka, 2017). Kalkan (2011) menemukan bahwa penerimaan dukungan sosial dari teman memprediksi secara signifikan pada kesepian anak. Pada penelitian ini diketahui bahwa sumber dukungan sosial yang memiliki kontribusi paling tinggi yaitu yang berasal dari teman dekat, selanjutnya dukungan sosial yang berasal dari teman sekelas memiliki kontribusi terbesar kedua, disusul dengan dukungan sosial dari orang tua dan guru. Hasil tersebut sesuai dengan 
tahap perkembangan sosio-emosional anak-anak usia akhir yang pada dasarnya lebih suka menghabiskan waktu bersama temannya dibanding dengan orangtuanya (Santrock, 2013).

Anak merasa lebih membutuhkan dukungan sosial yang berasal dari teman dibandingkan dari orangtuanya karena berdasarkan perkembangan sosio-emosionalnya, anak usia akhir mulai melakukan perbandingan sosial. Artinya anak mulai membandingkan dirinya dengan temannya, sehingga anak banyak melakukan aktifitas-aktifitas bersama sebagai cara untuk membandingkan dirinya dengan teman-temannya tersebut. Mereka berbagi cerita bersama, bermain bersama, menghabiskan waktu luang dengan melakukan hobi yang sama, dan sebagainya. Jadi dukungan yang diberikan oleh teman berupa dukungan emosional dan dukungan informasi. Data demografis pada penelitian ini menunjukkan bahwa anak laki-laki merasa memiliki dukungan sosial offline yang lebih rendah dan merasa lebih kesepian daripada perempuan. Hal ini sesuai dengan penelitian Liu, Li, Purwono, Chen, dan French (2015) yang menyatakan bahwa remaja laki-laki dilaporkan lebih merasa kesepian daripada perempuan.

Penelitian ini juga menemukan bahwa semakin tinggi dukungan sosial offline, berdampak pada menurunnya kecenderungan adiksi video game secara langsung. Justin, Patry, Burgess, Thomas, LaPorte, Mason, dan Haber (2013) menemukan bahwa dukungan sosial offline merupakan faktor protektif terhadap Problematic Internet User. Dukungan sosial online tidak berhubungan dengan PIU secara umum, namun, ketika dukungan sosial offline rendah, dukungan sosial online muncul sebagai faktor risiko. Dukungan sosial offline dan online berhubungan dengan beberapa variabel yang mencerminkan konteks sosial pengguna MMORPG, dengan dukungan sosial offline menunjukkan hubungan yang konsisten lebih kuat daripada dukungan sosial online. Selama dukungan sosial offline tinggi, dukungan online tidak akan memiliki dampak merugikan yang menimbulkan kekhawatiran dalam beberapa literatur MMORPG yang ada. Lin, Wu, You, Chang, Hu, Xu (2018) juga menyatakan hal yang serupa bahwa individu yang tidak menerima dukungan sosial dari orang di sekitarnya cenderung menggunakan internet lebih sering. Hal ini sejalan dengan hasil data demografis pada penelitian ini yang menunjukkan bahwa anak dengan dukungan sosial offline yang tinggi memainkan game dengan durasi paling sedikit yaitu antara 1-2 jam. Terdapat perbedaan yang signifikan ditinjau dari faktor durasi bermain video game, yaitu semakin lama waktu yang digunakan anak untuk bermain video game menunjukkan kecenderungan adiksi video game yang lebih tinggi.

Berdasarkan rating game, terdapat perbedaan yang signifikan pada rata-rata kecenderungan adiksi video game, yang lebih tinggi adalah game dengan rating $16+$ dan rating $18+$. Anak yang memainkan game dengan rating $18+$ memiliki rata-rata dukungan sosial yang lebih rendah daripada rating yang lain. Anak dengan dukungan sosial offline yang lebih rendah cenderung memainkan game dengan rating yang lebih tinggi atau tidak sesuai dengan usianya. Beberapa orang yang memiliki masalah dalam menyesuaikan diri dengan lingkungannya dapat beralih dengan bermain video game karena mereka menerima pengakuan dari dunia digital yang dirasa berbeda dengan kehidupan nyatanya, sehingga mereka menghadapi risiko kecanduan video game yang lebih tinggi (King \& Delfabbro, 2009). Orang yang bermain video game untuk menghindari tekanan atau melarikan diri dari dunia nyata cenderung memiliki resiko tinggi untuk penggunaan yang bermasalah karena bermain video game membantu mereka mengatasi stress, video game juga membuatnya tertarik, sehingga menjauhkannya dari kehidupan normal daripada harus menghadapinya (Seay, Fleming, \& Kraut, 2007). Orang-orang di sekitar pemain yang patologis dapat membantu meminimalisir adiksi video game dengan dukungan sosial, baik secara nyata maupun maya, telah terbukti meningkatkan kesehatan fisik dan menurunkan gejala psikologis seperti depresi dan kecemasan (Longman, 2009).

Hipotesis dalam penelitian ini tidak terbukti yaitu kesepian tidak mendukung dugaan perannya sebagai mediator bagi rendahnya dukungan sosial offline dan kecenderungan adiksi video game. Hasil efek langsung rendahnya dukungan sosial offline terhadap kecenderungan 
adiksi jauh lebih tinggi dibandingkan efek tak langsung melalui variabel kesepian. Artinya bahwa anak yang mendapat dukungan sosial offline yang rendah berpotensi mengalami kesepian, namun belum tentu mengalihkan perasaan kesepiannya tersebut dengan bermain video game. Terdapat faktor-faktor lain yang dapat lebih menjelaskan mengenai hubungan dukungan sosial offline yang rendah dan kecenderungan adiksi video game selain kesepian. Berbeda dengan hasil penelitian ini, Prabowo dan Juneman (2012) membuktikan bahwa kesepian merupakan mediator hubungan antara penerimaan teman sebaya dan kecanduan bermain game daring pada remaja di Jakarta. Hasil penelitian tersebut menyatakan bahwa semakin remaja yang bermain video game mempersepsikan dirinya tidak diterima oleh teman sebaya, bila diikuti dengan kesepian, semakin tinggi tingkat kecanduannya terhadap video game daring.

Hipotesis pada penelitian ini ditolak, namun berdasarkan analisis dengan regresi berganda ditemukan bahwa baik variabel rendahnya dukungan sosial offline dan variabel kesepian secara bersama-sama merupakan prediktor bagi kecenderungan adiksi video game. Artinya bahwa rendahnya dukungan sosial offline dan kesepian dapat memprediksi kecenderungan adiksi video game secara signifikan. Serupa dengan hasil penelitian ini, Cevic dan Yildiz (2017) juga mengungkapkan bahwa dukungan sosial dari orang-orang di sekitar, kesepian, serta jenis strategi coping cognitive avoidance dan problem solving dapat memprediksi kecanduan internet pada remaja secara signifikan.

Ditinjau dari pemilihan skala dukungan sosial yang digunakan pada penelitian ini dikaitkan dengan harga diri anak yaitu bagaimana anak merasa dirinya dicintai, berharga dan bernilai (Harter, 2012). Artinya bahwa ketika anak merasa memiliki dukungan sosial offline yang rendah, anak membutuhkan cara untuk mengkompensasi rendahnya harga diri yang dirasakan akibat kurangnya dukungan sosial tersebut dengan cara bermain video game. Seperti yang dikemukakan oleh Wan dan Chiou (2006) bahwa bermain video game yang dilakukan terus menerus bisa jadi merupakan pengalihan untuk memuaskan kebutuhan psikologis pemain yang kecanduan tersebut. Jadi, dukungan sosial yang rendah pada penelitian ini lebih dekat kaitannya dengan rendahnya harga diri anak. Hal ini juga dapat menjadi alasan mengapa kesepian pada penelitian ini tidak terbukti sebagai mediator dalam hubungan antara rendahnya dukungan sosial offline dengan kecenderungan adiksi video game.

\section{KESIMPULAN}

Berdasarkan penjabaran tersebut dapat disimpulkan kesepian tidak berperan sebagai mediator hubungan antara rendahnya dukungan sosial offline dan kecenderungan adiksi video game, namun variabel kesepian dan rendahnya dukungan sosial offline berperan sebagai variabel prediktor terhadap kecenderungan adiksi video game. Sebagai tambahan temuan penelitian menunjukkan kesepian dalam penelitian ini rendah dapat menjadi alasan tidak terbuktinya variabel mediator. Konsep kesepian yang unidimensional pada penelitian ini tidak dapat menjelaskan apakah kesepian tersebut secara sosial atau secara emosional. Faktor budaya di Indonesia dapat menjadi alasan mengapa subjek pada penelitian ini memiliki kategori kesepian yang rendah, karena secara sosial, anak usia sekolah dasar masih memiliki kedekatan dengan orangtua, tetangga, dan lingkungan sosial lainnya, sehingga anak mungkin tidak merasa kesepian secara sosial, hal ini bisa menjadi masukan bagi penelitian selanjutnya. 


\section{DAFTAR PUSTAKA}

Bray, G. (2008). Effect of video and computer games on children. Trans. Pour Abedini Naeeni H. Tehran: Javaneh Roshd Publication

Cevik, G.B., Yildiz, M.A. (2017). The Roles of Perceived Social Support, Coping, and Loneliness in Predicting Internet Addiction in adolescents. Journal of Education and Practice Vol. 8, No. 12. ISSN 2222-1735 (Paper) ISSN 2222-288X (online)

Hagen, K.A., Myers, B.J., Mackintosh, V.H. (2005). Hope, Social Support, and Behavioral Problems in At-Risk Children. American Journal of Orthopsychiatry Vol 75, No. 2, 211-219. DOI: 10.1037/0002-9432.75.2.0

Harter, S. (2012). Social support scale for children: Manual and questionnaires revision of 1985 manual. Denver: Denver University.

Jogiyanto, H, \& Abdillah, W. (2016). Partial Least Square (PLS) untuk Penelitian Empiris. Yogyakarta: BPFE Fakultas Ekonomi dan Bisnis UGM

Justin, M; Patry, BS; Chuck, A; Burgess, BS; Thomas, M; Laporte, BA; Mason, G; Haber. (2013). online and offline Social Support and Health Among Massively Multiplayer online Role Playing Game Players. The University of North Carolina at Charlotte

Kalkan, M; Epli-Koc, H. (2011). Perceived Social Support From Friends as Determinant of Loneliness in a Sample of Primary School. US-China Education Review, ISSN 15486613, Vol. 8, No. 4, 547-551. Turkey: David Publishing

King, D., \& Delfabbro, P. (2009). Understanding and assisting excessive players of video games: A community psychology perspective. The Australian Community Psychologist, 21(1), 62-74

Knoetze, J. S. (2012). An Emotional Awareness Program for Children in Middle Childhood, for Utilization in Educational System. Thesis. Faculty Of Humanities: University of Pretoria

Kusumadewi T. N. (2009). Hubungan antara kecanduan internet game online dan keterampilan sosial pada remaja. Skripsi. Jakarta: Universitas Indonesia

Lemmens, J. S., Valkenburg, P. M., \& Peter, J. (2009). Development and Validation of a Game Addiction Scale for Adolescents. Media Psychology, 12 (1), 77-95. https://doi.org/10.1080/15213260802669458

Lemmens, J. S., Valkenburg, P. M., \& Gentile, D. A. (2015). The Internet Gaming Disorder Scale. Psychological Assessment, 27 (2), 567-582. https://doi.org/10.1037/pas0000062

Leung, L. (2011). Loneliness, social support, and preference for online social interaction: the mediating effects of identity experimentation online among children and adolescents. Chinese Journal of Communication, Vol 4, No. 4, 381-399

Lin, M.P., Wu, J.Y., You, J., Chang, K., Hu, W., Xu, S. (2018). Association between online and offline social support and internet addiction in a representative sample of senior high school students in Taiwan: The mediating role of self-esteem. Computers in Human Behavior, doi: 10.1016/j.chb.2018.02.007

Liu, J; Li, D; Purwono, U; Chen, X; French, DC. 2015. Loneliness of Indonesian and Chinese Adolescents as Predicted by Relationships With Friends and Parents. Merrill-Palmer Quarterly Vol. 61, No. 3

Longman, H., O’Connor, E. L., \& Obst, P. L. (2009). The effect of social support derived from World of Warcraft on negative psychological symptoms. Cyber Psychology and Behavior, 12(5), 563-566.

Pontes, H.M., Griffiths, M.D., Patrao, I.M. (2014). Internet Addiction and Loneliness Among Children and Adolescents in the Education Setting: An EMpirical Pilot Study. Aloma, 32 (1), 91-98. ISSN: 1138-3194 
Poole, E.S., Eiriksdottir, E., Miller, A.D., Xu, Y., Catrambone, R., Mynatt, E.D. (2013). Designing for Spectators and Coaches: Social Support in Pervasive Health Games for Youth. $7^{\text {th }}$ International Conference on Pervasive Computing Technologies for Healthcare and Workshops. DOI 10.4108/icst.pervasivehealth.2013.252157

Prabowo, O., Juneman. (2012). Penerimaan Teman Sebaya, Kesepian, dan Kecanduan Bermain Gim Daring Pada Remaja di Jakarta. Mimbar Jurnal Sosial dan Pembangunan, Vol. 28, No.1

Rotenberg, K.J., Macdonald, K.J., King, E.V. (2004). The Relationship Between Loneliness and Interpersonal Trust During Middle Childhood. Genetic Psychology 165, 233-249

Santrock, J.W. (2013). Life Span Development $14^{\text {th }}$ ed. New York: McGraw-Hill Companies, Inc.

Seay, A., Fleming, \& Kraut, R. E. (2007). Project Massive: Self-regulation and problematic use of online gaming. Proceedings from CHI 2007: San Jose, CA, USA

Tabak, I., Zawadzka, D. (2017). Loneliness and Internet Addiction of Polish Adolescents. Psychiatry Psycology Klin, 17 (2), 104-110. DOI: 10. 15557/PiPK.2017.0011

Tavormina, M.G.M., Tavormina, R. (2017). Playing with Video Games: Going to a New Addiction?. Psychiatria Danubina (Suppl 3), 422-426

The Asian Parent Insight. (2014). Mobile Device Usage Among Young Kids: A Southeast Asia Study. Samsung Kidstime ${ }^{\mathrm{TM}}$.

Wan CS, Chiou WB. (2006). Why are adolescents addicted to online gaming? An interview study in Taiwan. Cyberpsychology Behavior 9(6): 762-6.

Wimbarti, S dalam Nurazhar (2018). Gence: Membedah Anatomi Peradaban Digital. Bandung: Tasdiqiya Publisher

Yeh, Y., Ko, H., Wu, J., Cheng, C. (2008). Gender Differences in Relationships of Actual and Virtual Social Support to Internet Addiction Mediated Through Depressive Symptoms among College Students in Taiwan. Cyberpsychology and Behavior, Vol. 11, No. 4. Mary Ann Liebert, Inc. DOI: 10.1089/cpb.2007.0134 